\title{
The spatio-temporal evolution of the genus Nitzschia Longissima at the level of the lagoon in Nador, Morocco
}

\author{
Ouassila Riouchi $^{1, *}$, Faid El Madani ${ }^{2}$, Eric Abadie ${ }^{3}$, Ali Skalli $^{1}$, and Mourad Baghour ${ }^{1}$ \\ ${ }^{1}$ OLMAN-RL, Nador Multidisciplinary Faculty (FPN), Nador, Mohamed 1st University, Morocco. \\ ${ }^{2}$ INRH-Nador Regional Center, 13 Boulevar Zerktouni BP: 493, Nador, Morocco. \\ ${ }^{3}$ Ifremer, Laboratoire Environnement Ressources du Languedoc-Roussillon, Centre for Marine Biodiversity, Exploitation and \\ Conservation (MARBEC), CS30171 Sète Cedex 03 34200, France.
}

\begin{abstract}
This work aims to study the spatio-temporal evolution of the genus Nitzschia longissima, one of the most important genera of marine plankton diatoms, from 3 sampling stations in the Nador lagoon and during 2 seasons (spring and summer 2018), Using Nitzschia longissima, as a study system, one of the most diverse and abundant genera among marine planktonic diatoms. This species counts, in addition to the form Nitzschia longissima forma parva Grunow, three varieties namely Nitzschia longissima var. closterium (W. Smith) Van Heurck, Nitzschia longissima var. longissima (Breb.) Ralfs and Nitzschia longissima var. reversa Grunow. Nitzschia Longissima genus density was high during the warm season (Summer 2018) with a value of 8000 cells/liter, and low during the cold seasons (Spring 2018), which may be caused by water temperature and zooplankton community structure; and underwater light intensity was an important factor influencing the spatial distribution of Nitzschia density.
\end{abstract}

\section{Introduction}

Several scientific studies have been published on coastal lagoons focusing on their hydrology, geochemistry, biology and ecological classification criteria $[1,2,3,4,5,6]$. Coastal lagoons are shallow bodies of water, located in a transition zone between the terrestrial and marine ecosystem, found on all continents, generally oriented parallel to the coast, separated from the ocean by a barrier or lido, connected to the ocean by one or more open channels, at least intermittently [7] . On the Moroccan Mediterranean coast there is only one lagoon, located in the north-eastern region: Nador Lagoon or Sebkha Bou Areg or Mar Chica. The Nador lagoon, located on the Moroccan Mediterranean coast between the Cap des Trois Fourches and the Cap de l'Eau, is of great socio-economic interest for the region where different types of activities are carried out, especially those related to artisanal fishing. This lagoon has been the subject of various studies aimed at understanding the functioning of its ecosystem. $[8,9]$ but those relating to its hydrodynamics are very few. $[10,11]$.

It is integrated into the whole geodynamic context of the Western Mediterranean. Indeed, its genesis and evolution are governed by the neotectonic evolution of the Rifane chain built in the Mio-Plio-Quaternary [12]. This lagoon is highly urbanized at its periphery and subject to significant anthropogenic pollution. This lagoon was first studied by the Spaniards, who,through their prospecting trips, have described its geographical, orographical, hydrological and hydrographic characteristics [13].

\section{Materials and methods}

A specific sampling strategy was implemented in order to determine the spatio-temporal variability of phytoplankton communities of the genus Nitzschia longissima in the Nador lagoon. This lagoon is considered the largest lagoon in Morocco, with a length of $25 \mathrm{~km}$, a width of $7.5 \mathrm{~km}$ and an estimated area of $115 \mathrm{~km} 2$. It is also considered the second largest lagoon complex in North Africa [14,15]. The sampling campaigns were carried out at a seasonal frequency (spring and summer 2018), at 3 stations: which corresponds to Tirakae St1, Nador Wastewater Treatment Plant St2 and Kariat Arakman St3. This study consists in carrying out a quantitative study of the genus "Nitzschia longissima" and physico-chemical analyses of the water of the lagoon of Nador in situ using specific probes such as : (Temperature " T ", pH, Salinity, Dissolved Oxygen " DO ") and Suspended Matter " TSS " were carried out ex situ.

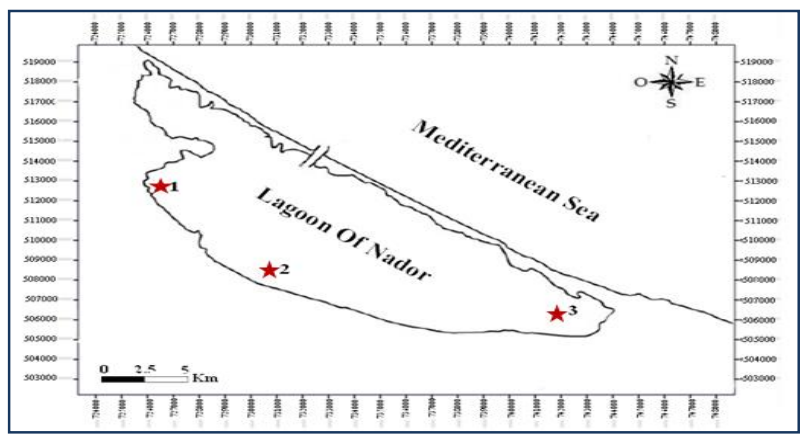

Figure 1: The distribution of sampling stations.

*Corresponding author: Ouassila.riouchi@gmail.com 


\section{Results and Discussion}

The $\mathrm{pH}$ of the Nador lagoon recorded at the level of the 3 stations sampled in the two study periods, oscillated between a minimum of 8 at the level of station 2 which corresponds to the treatment plant during the summer period. A maximum of 8.47 recorded is observed at the level of station 3 and during the spring period, Our results are similar to those found by [16] (Fig.2) At the level of the Nador lagoon MES recorded at the 3 sampled stations vary from a minimum of $0.7 \mathrm{~g} / \mathrm{lat}$ station 1 during the Spring period. A maximum of $3.4 \mathrm{~g} / \mathrm{l}$ recorded at station 3 and during the summer period.(Fig.3)The water temperature of the Nador lagoon measured during the study period varies between a minimum value of $17.5^{\circ} \mathrm{C}$ recorded in the Spring period at station 1 and a maximum value of $24.2^{\circ} \mathrm{C}$ recorded at station 3 during the Summer period, Our results are similar to those found by [16]. (Fig.4) Dissolved Oxygen measured at the 3 study stations of the Nador lagoon reaches a maximum of $10 \mathrm{mg} / \mathrm{l}$ at station 3 at the spring period this value is comparable to that found by [17]. A minimum of $7.2 \mathrm{mg} / \mathrm{l}$ in station 1 during the summer period this value is comparable to that found by [16]. (Fig.5) The minimum value of Salinity recorded at the Nador lagoon has a minimum value of 34.8 in station 2 , during the spring period. However, the Maximum value noticed at the level of station 1 and during the summer month with a value of 36.5. (Fig.6)

According to Figure 7 , it is clearly noticed that the cell density of Nitzschialongissima of the waters of the Nador lagoon, recorded at the level of the 3 sampled stations, in the period of (spring 2018), oscillated between a minimum of 500 cells/liter, observed at Station 1 and a maximum of 800 cells/liter at Station 2 which corresponds to the Wastewater Treatment Plant. However the period (summer 2018), the minimum and maximum cell density of Nitzschialongissima recorded at the level of the 3 stations sampled in the Nador lagoon were respectively 500 cells/liter at station 3 and 8000 cells/liter at station 1 .

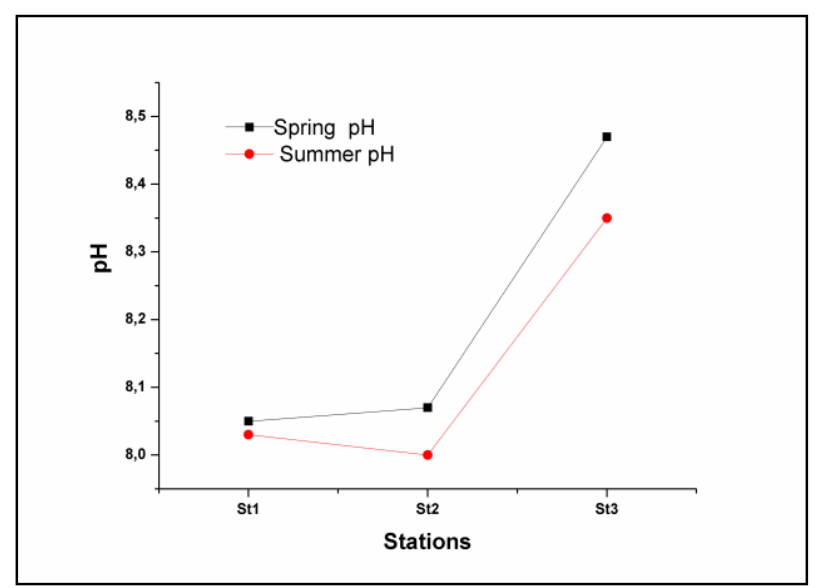

Figure2: Spatial variation of the $\mathrm{pH}$ of the Nador lagoon in spring and summer.

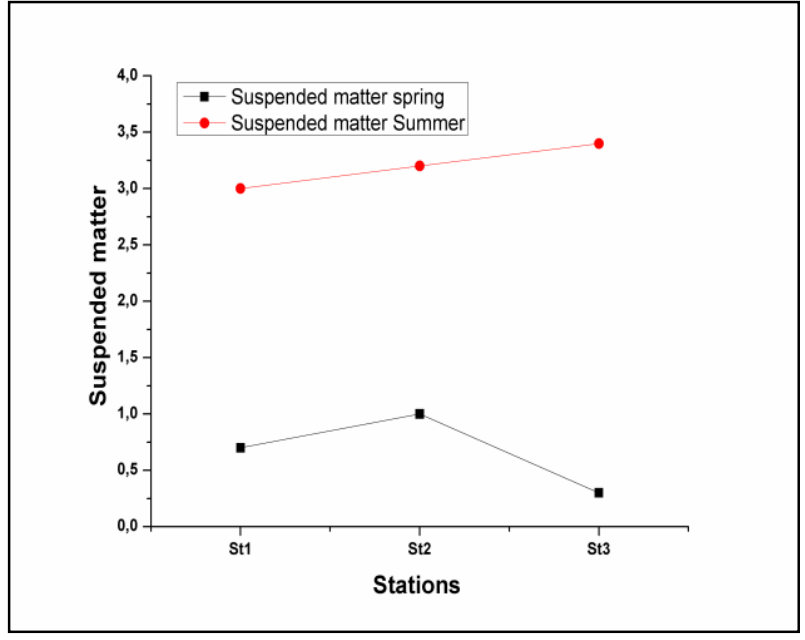

Figure 3: Spatial variation of the MES of the Nador lagoon in spring and summer.

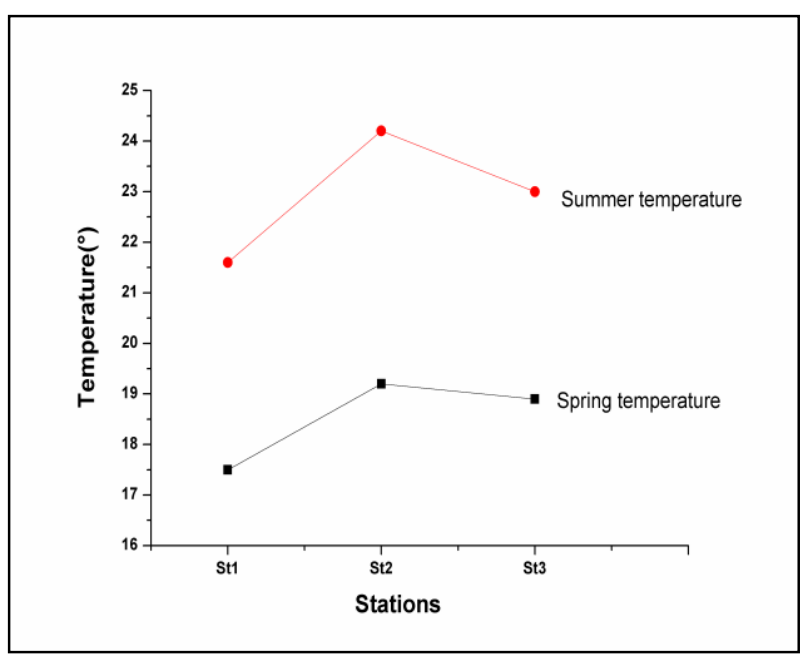

Figure 4: Spatial variation of the temperature of the Nador lagoon in spring and summer.

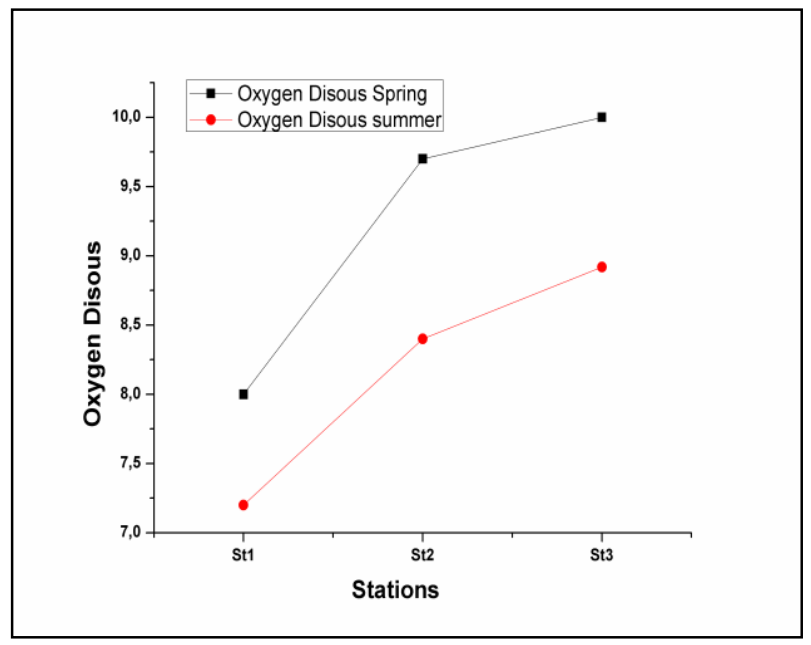

Figure 5: Spatial variation of dissolved oxygen of the Nador lagoon in spring and summer. 


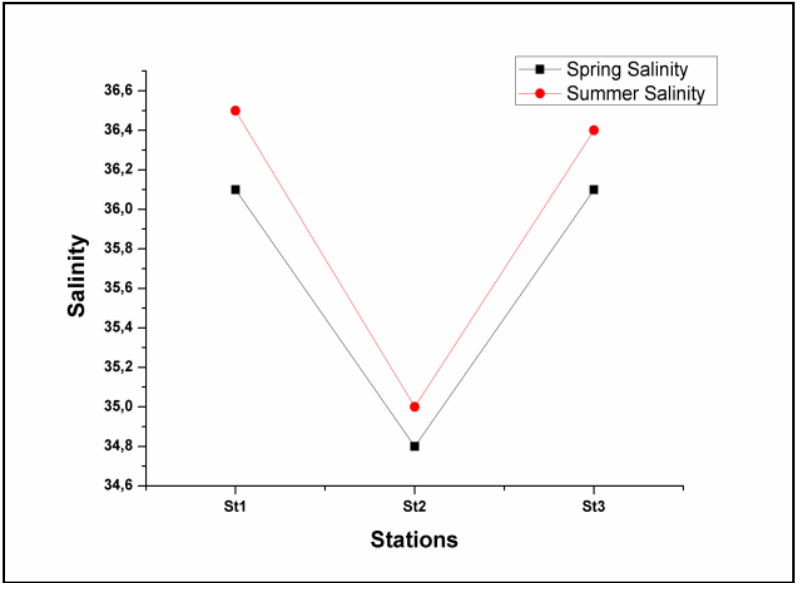

Figure 6: Spatial variation of the salinity of the Nador lagoon in spring and summer

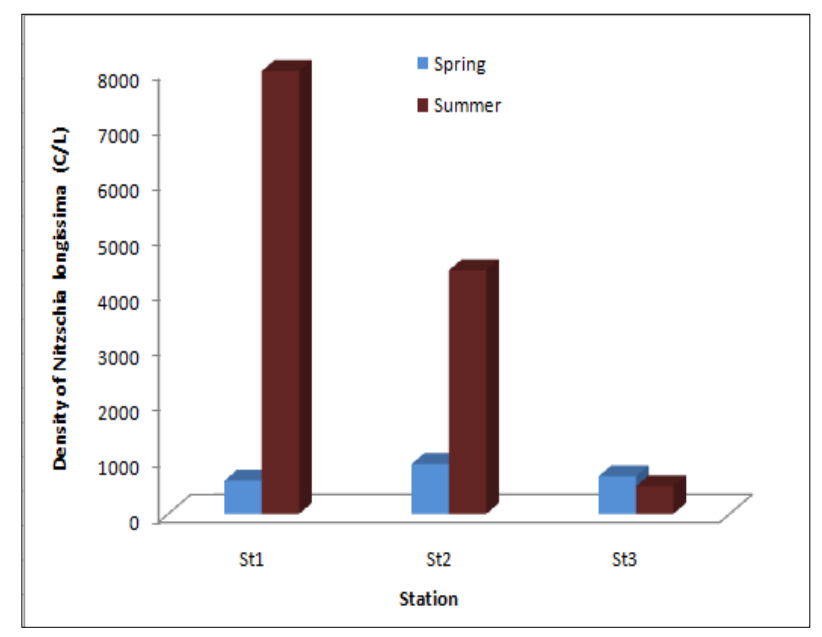

Figure 7: Spatial variation of the density of N.Longissima of the Nador lagoon in spring and summer

\section{Conclusion}

This present study showed that at the level of the Nador lagoon, the genus Nitzschialongissima was presented during the study period (spring and summer 2018). However, at the time of its appearance, the genus Nitzschialongissima showed high cell abundances 8000 cells/liter were observed during the summer period. This abundance may be caused by water temperature and zooplankton community structure. The response of cells to different temperatures is variable depending on the species of microalgae [18]In addition, temperature variations will have an impact on the assimilation of inorganic carbon. First, indirectly because the higher the temperature, the less $\mathrm{CO} 2$ will dissolve in the water. In addition, the balance between the different species will be modified and therefore their concentration in the medium. The abundance of Nitzschialongissima coincided with a high temperature concentration.

\section{References}

1. [1] Den Hartog, C. (1974). Brackish-Water Classification, Its Development And Problems.
Hydrobiological Bulletin, (1-2).

2. [2] Jonge, V N De. 1974. «Classification of brackish coastal inland waters ». Hydrobiological bulletin 8 (1-2). Springer: 29-39.

3. [3] Tesson, Michel. 1977. «REGIME HYDROLOGIQUE ET HYDRODYNAMIQUE DE LA SEBKHA BOU AREG.(LAGUNE DE NADOR-MAROC). BILAN DU PRINTEMPS 1976. »

4. [4] Tesson, M., B. Gensous, 1981. Quelques Caratères De La Géochimie D'une Lagune MicroTidale : La Sebkha Bou-Areg (Maroc). 106e Congr. Natl. Des Sociétés Savantes, Perpignan, 1981, Sciences, Fasc. III, 183-194.

5. [5] Guélorget, O., J.P. Perthuisot, G.F. Frisoni \& D.

6. Monti, 1987. Le Rôle Du Confinement Dans L'organisation Biologique De La Lagune De Nador (Maroc). Oceanol.Acta $10: 435-444$.

7. [6] Dutrieux, E. \& Guélorget O., 1991. Ecological Planning : A Possible Method For The Choice Of Aquaculture Sites. Workshop On Lagoon Management, Nador-Morocco.

8. [7] Kjerfve, Björn. 1994. «Coastal lagoons ». In Elsevier oceanography series, 60:1-8. Elsevier.

9. [8] Abouhala A., Boukabous R., Dafir, J.E. and Talbaoui, E..M., 1995. Caractérisation physicochimique de la lagune de Nador. Actes Inst. Agro. Vet. (Maroc), Vol. 15 (4), 45-52.

10. [9] LEFEBVRE A, GUELORGET O, PERTHUISOT J, DAFIR J. 1997. ÉVOLUTION BIOLOGIQUE DE LA LAGUNE DE NADOR (MAROC) AU COURS DE LA PERIODE 19821993. OCEANOLICA ACTA 20: 371-85

11. [10] Hilmi K., Koutitonsky V.G., A. Orbi and Chagdali M., 2005. Threedimensional water circulation and dispersion in Nador lagoon (Morocco). In: Lasserre et al. (Eds), IOC Integrated Coastal Area Management (ICAM), Dossier N॰3, pp. 171-177.

12. [11] Hilmi K., 2005. Modélisation numérique de la circulation de deux milieux paraliques du littoral marocain: la lagune de Oualidia (Atlantique) et la lagune de Nador (Méditerranée). Thèse de doctorat, Université Hassan II Mohammadia (Maroc), 186 p.

13. [12] Guillemin, M., Houzay, J.-P., 1982. Le Néogène post-nappes et le Quaternaire du Rif nordoriental ; Stratigraphie et tectonique des bassins de Melilla, du Kert, de Boudinar et du piedmont des Kebdana. Editions du Service géologique du Maroc.

14. [13] Delongueville et R. Scaillet, «Hexaplex trunculus (Linnaeus, 1758)», NOVAPEX/Société, vol. $4, n^{\circ} 2-3$, p. 57,2003

15. [14] Zerrouqi Z., Sbaa M., Chafi A., Aqil H., Bull. Inst. Sci. Rabat. 35 (2013) 51-59.

16. [15] Ruiz F, Abad M, Olías M, Galán E, González I, Et Al. 2006. The Present Environmental Scenario Of The Nador Lagoon (Morocco). Environmental Research 102: 215-29

17. [16] Mostareh. 2017. «Principe de l'analyse 
factorielle. 34p ». In , 217Pp. MOSTAREH.M. 2017.Impact de l'ouverture de la nouvelle passe de la lagune de Nador sur l'organisation spatiotemporelle du peuplement phytoplanctonique. Université Mohamed Premier.217Pp.

18. [17] Aknaf, Asmae et al. 2017. «Spatial Evolution of Physical-Chemical Parameters Characterizing the Quality of the Surface Waters After the Developpement of the Marchica Lagoon (NorthEast Morocco) ». In Euro-Mediterranean Conference for Environmental Integration, Springer, 763-66.

19. [18] O. Necchi Jr et M. R. Zucchi, «Photosynthetic performance of freshwater Rhodophyta in response to temperature, irradiance, $\mathrm{pH}$ and diurnal rhythm », Phycol.Res., vol. 49, no 4, p. 305-318, 2001.

20. [19] Beardall, J., Stojkovic, S., 2006. Microalgae under global environmental change: Implications for growth and productivity, populations and trophic flow.ScienceAsia, 1-10. 